\title{
Why so Many Chinese Students Come to the U.S. for their Higher Education
}

\author{
Chiang-nan Chao ${ }^{1}$ \\ ${ }^{1}$ St. John's University \\ 8000 Utopia Parkway, Jamaica, New York, USA \\ Email: chaoc [AT] stjohns.edu
}

\begin{abstract}
This study focuses on why Chinese students come to the U.S. for their higher education. This student population plays a vital role in American colleges and universities, and provides a much needed source of financial revenue. The results indicate that Chinese students are seeking education with a worldview and opt to break from the Chinese system of learning. This article seeks to offer both academicians and university administrators a better understanding of the reasons of these Chinese students, and contributes to the knowledge area extant on this population.
\end{abstract}

Keywords - International students, Chinese students in U.S.

\section{INTRODUCTION}

The international students coming to the U.S. for higher education have a significant positive economic impact on the United States. International students contributed \$39.4 billion to the U.S. economy in 2016/17, according to the U.S. Department of Commerce (Report of Open Door, 2017). By any measure, international education makes a significant contribution to the U.S. economy. The latest analyses find that the $1,078,822$ international students studied at U.S. colleges and universities, and they contributed $\$ 36.9$ billion and support more than 450,000 jobs to the U.S. economy during the 2016/17 academic year. The economic contributions of international students are in addition to the immeasurable academic and cultural value these students bring to US campuses and local communities (NAFSA International Student Economic Value Tool, 2017). In New York State, international students contributed $\$ 4.6$ billion, and supported 55,851 jobs. The economic impacts are not limited to the spending made by these foreign students, but also their families residing in the host country (NAFSA, Report 2017). Of all international students, about 65\% of source of funding comes from students' families. Meanwhile, many U.S. universities are facing an increasingly tough financial situation with a shortage of domestic students, a decrease in corporate support, and declines in government subsidies. In such a situation, Chinese students with money to spend may fill that financial gap (WES Report, 2015; Joseph, 2012). St. John's University, New York, ranked the 16th that had contribution from international students, with $\$ 80.8$ million spent, and generated 1,060 jobs in 2016 (NAFSA Report, 2016). Conversely, countries that see their students study abroad normally hope that these students return home and contribute to their home economy. Attracting the best students from around the world has become a large and growing global export opportunity (2016 Top Markets Reports Education, 2016).

The U.S. has maintained its leading position for attracting international students, while China has become the largest single source of international students studying in the United States. As the economic impacts of the international students are substantial, educators and researchers seek to understand this phenomenon and identify better ways to serve this population, not only as an educational strategy, but also an international business strategy. This research, through an empirical setting intends to explore the drives of Chinese students who choose to study in the U.S. in order to provide insights and direction for educators, university administrators, and trade administrators.

\section{LITERATURE REVIEW}

For thousands of years, education has been placed as a top priority by Chinese families. China's economic reforms during the past decades have led a rapid growth in wealth and a shrinking family size. Thus, Chinese families to send children to international universities has become less burdensome. On the other hand, Chinese parents are tired of an education system that focuses mainly on academic scores at the expense of pupil's overall development, and many other drawbacks in China's educational system, make them seriously consider sending their children abroad for higher 
education (Yan, 2015).

The first group of 108 Chinese students came to study in American universities in 1880 (The Chinese-American Museum of Chicago, 1880). The inflow of the Chinese students in the U.S. between 2009 and 2016 grew at a double digits, from 2009/10 to 2012/13 academic years, the growth rates kept at more than 20 percent a year. It is unlikely that the exponential growth in Chinese students in the U.S. of the last decade will continue indefinitely. U.S. institutions are increasingly focused on diversifying their campuses and are hesitant to depend on foreign students from any individual country. In addition, the Chinese Government has significantly increased its efforts to build universities in China, which could emerge as new competitors to U.S. institutions. Chinese institutions are also under pressure from the government to offer academic programs that facilitate an easier way to employment, other English-speaking countries also offer education in English and at a lower cost in tuition and fees than many U.S. institutions. The Internet and social media serve as critical components for successful recruitment. It is also important to note that Chinese families from smaller cities in China's interior provinces have the financial resources and interest to participate in studying abroad. Second and third-tier Chinese cities are an excellent market for U.S. schools and colleges interested in recruiting Chinese students (2016 Top Markets Report-Education).

In 2016/17 academic year, the growth rates of the Chinese students in the U.S. dipped to a single digit of 6.8 percent, while the overall international students dropped 3.3\%, the first decline in a decade (Report of Open Door, 2017). New Enrollments by Foreign Students at U.S. Campuses on the Decline, the Wall street Journal, November 13, 2017. Source: https://www.wsj.com/articles/new-enrollments-by-foreign-students-at-u-s-campuses-on-the-decline-1510549260).

During this academic year, there were a total of 350,775 Chinese students enrolled at US universities, representing 32.5\% of the total international students. The decline in growth rate could be traced to a 2014 change in visa terms for Chinese students. Their visas are now good for five years, instead of one, meaning there are fewer visa renewals but not necessarily fewer students (Meckler \& Korn, 2018). Figure 1 shows the ten years percentage changes of the Chinese students in the U.S.

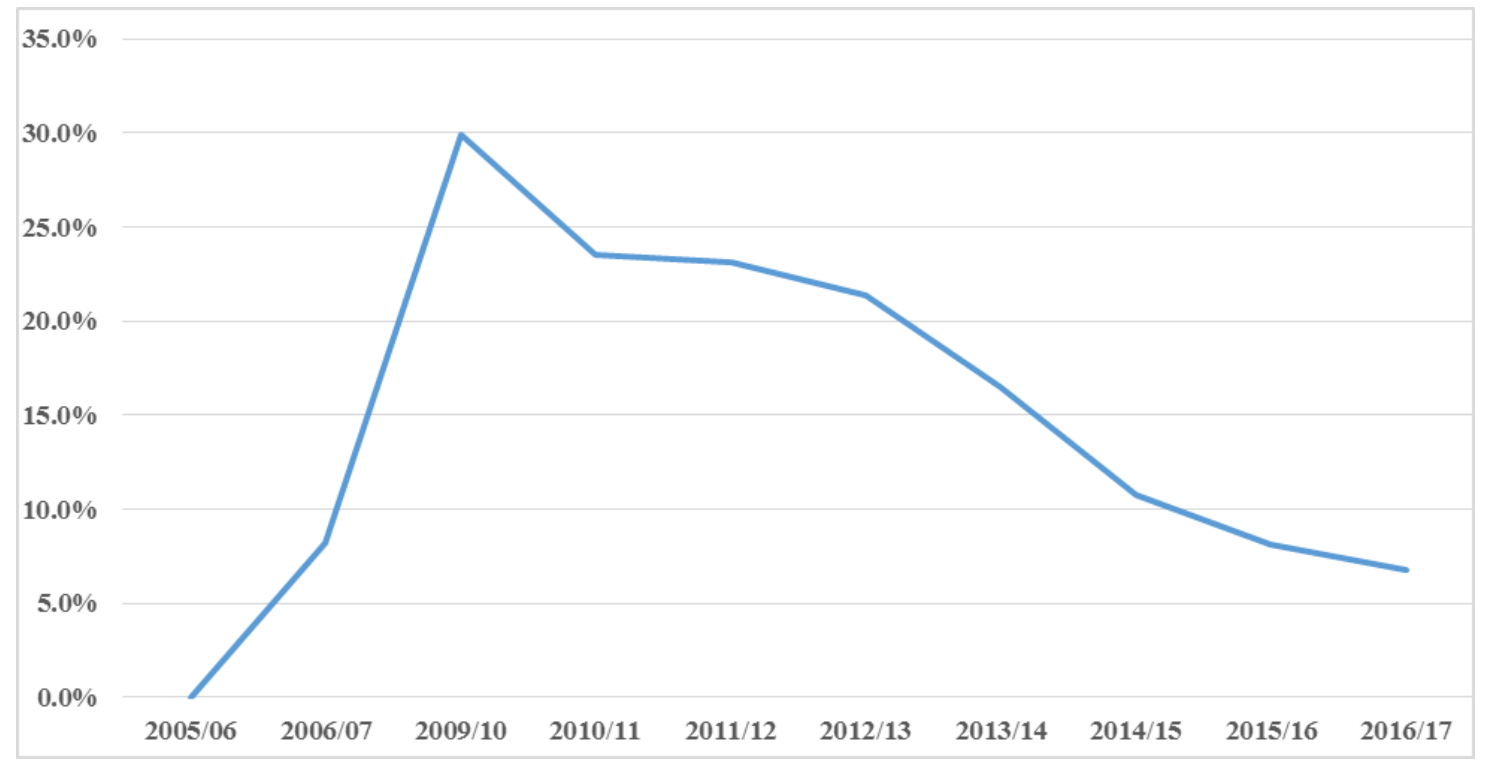

Figure 1. Ten years percentage changes of the Chinese students in the U.S.

American businesses, management knowhow, and capital have been flowing to China for the past years since China opened its door in the early 1980s, but it is education that reverses the tide. The benefits of studying abroad are felt both by individuals and entire nations. For these reasons educators and researchers are interested in the reasons that encourage Chinese students study in the U.S.

For Chinese students in the 2016/17 year, the top fields of study are business/management. Among all the majors, $23.1 \%$ of Chinese students choose business and management, the knowledge and skills enable Chinese students to find employments in China, however, that a decline from 29\% in 2012/13 (IIE DATA, 2017; Ortiz et al, 2015). Figure 2 presents the major fields of study for the Chinese students in the U.S. 


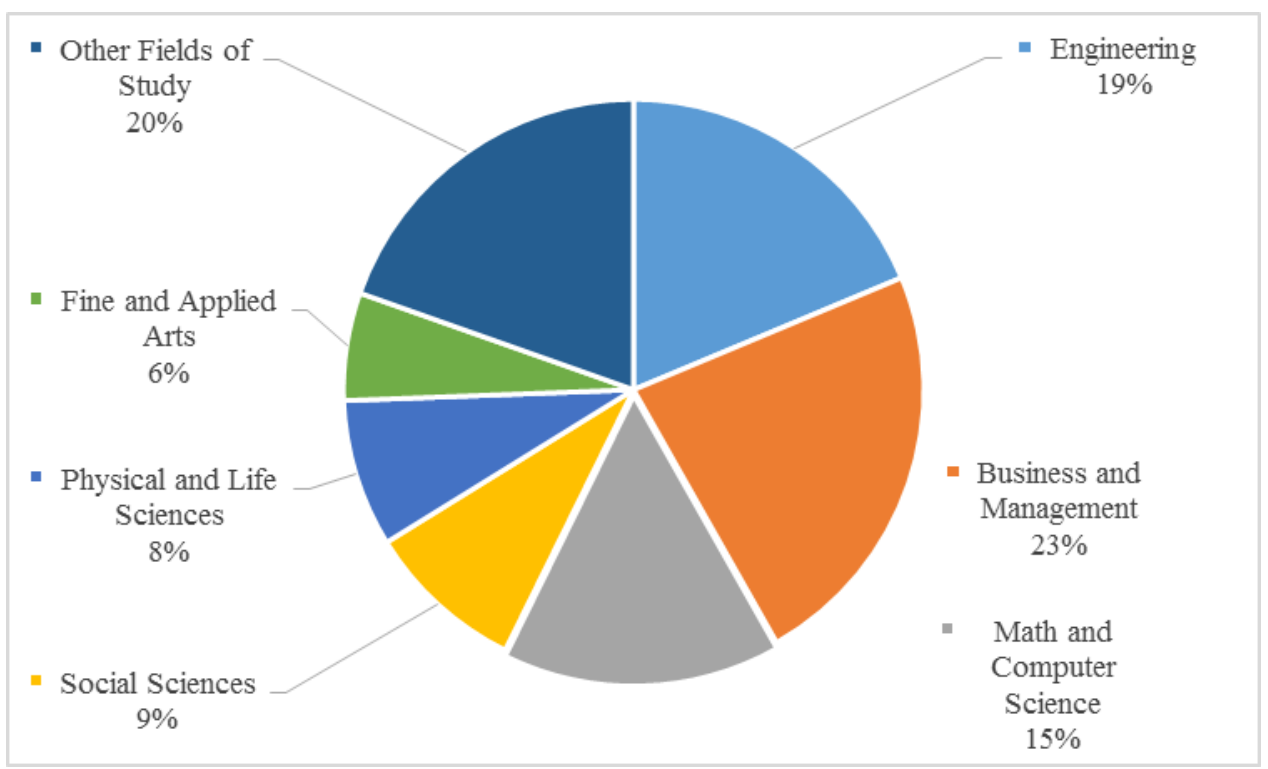

Figure 2. Major fields of studies for Chinese students in U.S.

Besides economic wellbeing, many Chinese parents and their kids decide to study abroad because they believe there is a better quality education in foreign countries. The growth in Chinese students may also reflect a confluence of factors. First, more Chinese citizens are completing college and thus eligible to apply to graduate schools. Many schools have set up their gateway offices in China, i.e. Columbia University and Ohio State University. Meanwhile, new specialized master's programs appeal to students, particularly those from China, eager to delve deeper into a single subject and gain a credential to compete with the growing population of educated young adults, without taking much time out of the workforce (Ozturgut \& Murphy, 2009; Yan, 2015; Albrecht, et al, 2012). Second, many U.S. schools are recruiting more aggressively overseas, marketing their programs to a wider talent pool. Word of mouth and social media then fuel the trend.

When looking into the Chinese applicants' backgrounds, many schools find some outstanding characteristics the Chinese applicants possess. First, they include China's best students who are probably aware that if they attend universities in China, they may not able to go to the best universities in the world, as among top 100 universities around the world, only one Chinese university is in 65th place by the U.S. News and World Report (U.S. News and World Report, 2017). Unlike U.S. institutions that value candidates who present themselves as unique, their Chinese counterparts want students who excel on entrance exams that require years of rote learning and possess a strong grasp of math and science. Some critics say China's state-run education system - promoted as the hallmark of Communist meritocracy - are being overrun by bribery and corruptions. Such a system has broadened the gulf between the privileged and non-privileged classes. Third, these young applicants are ambitious and many want to go to Ivy League schools, a symbol for those parents who raise their children successfully. Fourth, they desire to learn more about critical thinking, and very importantly, they want to be exposed to things aside from just test taking (Henze \& Zhu, 2012; Taylor, 2012; Wu, 2014; Ruiz, 2014; Soria1 \& Troisi, 2014).

Institute of International Education (IIE) published a report on reasons of the foreign students in the U.S. The report focuses on the following reasons:

1. Limited places available to study at (highly prestigious) universities in the home country;

2. Specialize in an area which is not offered in the home country;

3. Have access to specific laboratories/libraries not available/accessible in the home country;

4. Learn or improve knowledge of a foreign language;

5. Interest in foreign culture, history and landscape;

6. Get more practice-oriented education than offered in home country;

7. Possibility to build up networks/friendships in an intercultural context;

8. Improve career prospects/chances of getting a job in the home country;

9. Opportunity to develop the personality/become more independent; 
10. Get a broader/more flexible education than offered in home country;

11. Experience new ways of thinking and acting in the field of study;

12. Improve chances for an international career (2015 Top Markets Report).

The IIE report on reasons is rather general. Other research focuses more on what graduate courses the Chinese students choose rather than why they choose United Kingdom as their destination (Zheng, 2010; Russell, et al, 2010; Wu, 2014).

The research work by Chao and Hegarty (2014) focuses on the Chinese students' reasons for attending colleges in the U.S. Their results indicate that Chinese students are seeking education with a worldview and opt to break from the Chinese system of learning. Their study indicates choosing to study in the U.S. may be an academic endeavor, but the reasons behind the choices are not solely for academics. Due to its preliminary nature, it is questionable for generalization of the findings.

This article focuses in depth on the Chinese students' reasons for coming to the United States, so to provide some insights for educators and university administrators a better understanding of the Chinese students' reasons, therefore, serve this market segment better. This study samples a different Chinese student groups.

\section{RESEARCH METHODOLOGY}

With the focal questions in mind, this research focused on Chinese students' motives for studying in the U.S. A survey questionnaire was developed to investigate the issues related to the objectives of this study, Chinese students' motives to leave their home country and study in the U.S. Then the survey questionnaire was backwardly translated into Chinese to ensure the accuracy of the questionnaire, or in case some respondents may need a Chinese language questionnaire. However, all the respondents had an adequate grasp of the English questionnaire. The following variables were based on literature reviews.

\subsection{Variable Selection}

The following variables serve as reasons that affect Chinese students in their decision making for studying abroad derived from the literature review.

1. Gain a new perspective on my own country;

2. Can attend a better school overseas, but not able to attend the schools I want due to China National College Entry Exam;

3. It is easy to be admitted by a foreign school;

4. It is also costly if I study in my home country;

5. My friends have gone abroad, so I would;

6. I want to be away from my country;

7. I must study abroad because my parents' wish;

8. There are more fields of studies offered by foreign schools;

9. Political easiness in programs abroad;

10. Better living conditions, housing, eating, and environmental, i.e. clean air, etc;

11. The educational system is better overseas.

\subsection{Hypothesis, test of hypothesis, and sampling}

The hypotheses for this research are to find if there are any significant differences in the Chinese students' motives for choosing to study in the U.S.

H1 There is no significant difference for Chinese students to gain a new perspective between China and the U.S.

H2 There is no significant difference for Chinese students to attend a better school either in China or in the U.S.

H3 There is no significant difference for Chinese students to be admitted by a foreign school either in China or in the U.S.

H4 There is no significant difference for Chinese students to attend schools either in China or in the U.S. as far as cost is concerned. 
H5 There is no significant difference for Chinese students to attend school either in China or in the U.S. because their friends have gone.

H6 There is no significant difference for Chinese students to attend school either in China or in the U.S. as there is no difference between the two countries.

H7 There is no significant difference for Chinese students for where their parents wish them to study.

H8 There is no significant difference for Chinese students to find more fields of studies either in China or in the U.S.

H9 There is no significant difference for Chinese students to find political easiness in programs either in China or in the U.S.

H10 There is no significant difference for Chinese students living conditions, housing, eating, and environmental, i.e. Clean air, etc. either in China or in the U.S.

H11 There is no significant difference for Chinese students between the educational systems in China and the U.S.

Alternatively, there are significant differences in each of these hypotheses.

\subsection{Statistical test}

Due to the nature of this empirical study, the questionnaires were distributed to Chinese students in two large university campuses in the northeast America for a convenient sampling. The respondents were asked to evaluate the selected variables in a five point Likert scale, with $5=$ most important, $4=$ important, $3=$ neutral, $2=$ not important, and $1=$ least important.

One sample student's t-test is any statistical hypothesis test in which the test statistic follows a Student's t distribution if the null hypothesis is supported. It is most commonly applied when the test statistic would follow a normal distribution if the value of a scaling term in the test statistic were known. When the scaling term is unknown and is replaced by an estimate based on the data, the test statistic (under certain conditions) follows a Student's t distribution. The estimate value for testing hypotheses in this study is 3 which are either important or not important. The one sample t-test requires that the dependent variable follow a normal distribution. When the number of subjects in the experimental group is 30 or more, the central limit theorem shows a normal distribution can be assumed. If the number of subjects is less than 30 , the researcher should plot the results and examine whether they appear to follow a normal distribution. If the distribution appears to be non-normal, and/or if the number of test cases is significantly less than 30, then a one sample median test, which does not require a normal distribution, should be used to test the hypothesis. (Hamburg, 1977; Conover, 1980; Davis and Cosenza, 1985). Five percent of the t-tests one tailed probability level was selected to signify the differences between preferences.

\section{RESULTS}

Over 350 respondents were surveyed, with 128 completed responded for analyses, representing $36.5 \%$ of the total surveyed. Table 1 presents the general background information of the respondents.

Table 2: One-Sample t-Test Results, test value $=3$, neutral

\begin{tabular}{l|l|l|l|l}
\hline Variables & $\begin{array}{l}\text { Mean } \\
\text { Dif. }\end{array}$ & $\boldsymbol{d f}$ & $\boldsymbol{t}$ & \multicolumn{1}{c|}{ Sig. } \\
\hline 1. Gain a new perspective on my own country & $\mathbf{0 . 6 2 9}$ & $\mathbf{1 3 1}$ & $\mathbf{5 . 4 9 0}$ & $\mathbf{0 . 0 0 0}$ \\
2. Can attend a better school overseas, but not able to attend the schools I & & & & \\
want due to Gaokao. & 0.039 & 126 & 0.302 & 0.764 \\
3. It is easy to be admitted by a foreign school. & -0.292 & 129 & -2.698 & 0.008 \\
4. It is also costly if I study in my home country. & $\mathbf{- 0 . 5 5 4}$ & $\mathbf{1 2 9}$ & $\mathbf{- 5 . 0 7 0}$ & $\mathbf{0 . 0 0 0}$ \\
5. My friends have gone abroad, so I would & $\mathbf{- 0 . 6 6 4}$ & $\mathbf{1 3 0}$ & $\mathbf{- 5 . 6 2 7}$ & $\mathbf{0 . 0 0 0}$ \\
6. I want to be away from my country & $\mathbf{- 0 . 6 4 6}$ & $\mathbf{1 2 9}$ & $\mathbf{- 5 . 2 7 4}$ & $\mathbf{0 . 0 0 0}$ \\
7. I must study abroad because my parents' wish & $\mathbf{- 0 . 6 0 8}$ & $\mathbf{1 2 9}$ & $\mathbf{- 5 . 3 4 2}$ & $\mathbf{0 . 0 0 0}$ \\
8. There are more fields of studies offered by foreign schools. & 0.008 & 129 & 0.063 & 0.950 \\
9. Political easiness in programs abroad & $\mathbf{- 0 . 3 2 6}$ & $\mathbf{1 2 8}$ & $\mathbf{- 2 . 9 7 1}$ & $\mathbf{0 . 0 0 4}$ \\
10. Better living conditions, housing, eating, and environmental, i.e. clean air, & & & & \\
etc. & -0.115 & 130 & -0.996 & 0.321 \\
11. The educational system is better overseas. & $\mathbf{0 . 3 8 2}$ & $\mathbf{1 3 0}$ & $\mathbf{3 . 0 7 2}$ & $\mathbf{0 . 0 0 3}$ \\
\hline
\end{tabular}




\section{MANAGERIAL IMPLICATIONS AND RECOMMENDATIONS}

The mean differences as compared to the test value of 3 which is neutral tell the researchers how relatively important of these variables. The results show that seven variables, 1. Gain a new perspective on my own country, 4. It is also costly if I study in my home country, 5. My friends have gone abroad, so I would, 6. I want to be away from my country, 7. I must study abroad because my parents' wish, 9. Political easiness in programs abroad, and 11. The educational system is better overseas, show significant differences. Of these, variables 1. Gain a new perspective on my own country and 11. The educational system is better overseas show the positive mean differences, which mean the respondents view these variables more important. While other five variables, 4. It is also costly if I study in my home country, 5. My friends have gone abroad, so I would, 6. I want to be away from my country, 7. I must study abroad because my parents' wish, and 9. Political easiness in programs abroad show negative mean differences which mean that respondents view these variables less important. The hypotheses are rejected.

With regard to the other four variables, 2. Can attend a better school overseas, but not able to attend the schools I want due to Gaokao, 3. It is easy to be admitted by a foreign school, 8. There are more fields of studies offered by foreign schools, and 10. Better living conditions, housing, eating, and environmental, i.e. clean air, etc., the respondents express that these are less significant. This would suggest to the researchers these variables are less important for the Chinese students who study in the U.S. Some respondents indicate that it is as difficult as they apply for admissions at Chinese universities, especially the top tier universities. The hypotheses are accepted.

To supplement the survey, interviews of selected respondents were conducted. Some respondents indicate that Chinese Higher Education System lacks of innovation, and the students have to memorize the doctrines, rather than to find new ways of doing things. This gives credits to many US colleges that give Chinese students a worldwide view and encourage them to innovate. Some respondents expressed that their parents simply want them to have experiences in foreign schools. Several respondents indicate that the cost of studying at Chinese universities has rapidly increased in the past years, that makes those respondents chose to study abroad. "Catch up with Jones" is a fallacy for the Chinese students, rather than an important motive for their study aboard, simply some of their friends and/or classmates have gone to foreign universities. Many respondents indicate that they were aware that the job opportunities for international students were not good in North America, so that the majority respondents plan to return to China for jobs. The respondents also indicate that they come to study aboard, not subject to their parents' wishes, as they want to do at their own will. For variable 9. Political easiness in programs abroad, some respondents indicate that in the recent years, the Chinese universities ease political required courses.

What more comes through from this research is that non-academic reasons are primarily driving Chinese students to study in the U.S. Cultural aspects and desires to gain a non-Chinese world perspective emerge as primary motives for study in the U.S. This may be due to the understanding and realization by the Chinese of a global economy and the need to understand the 'internationalization' of business. These attitudes could also be considered to be consistent with attitudes of all affluent middle classes who have moved beyond daily sustenance and have achieved long term security.

\section{LIMITATIONS AND FUTURE RESEARCH}

While this study is limited by sample size and confined to Chinese students studying at only two universities in the northeast America it does provide direction and insight for future researcher to build upon. The sample size can be accepted as a good representation of the motives of Chinese students who wish to study in the U.S. as the northeast America, particularly New York State, has a larger number of Chinese students.

The Chinese students' reasons for coming to the U.S. may include more. The author took a special research tour recently in China to interview with the parents (some are grandparents) who have their children in the U.S. or plan to send their children to, indicate that they believe that higher education overseas is much better. As long as they can afford, their first choice is to let their children study overseas. Academic research on the reasons of international student populations ( $4 \%$ of the total US college students), particularly Chinese students (over $1 \%$ of the total US college students) in the U.S. is limited. While much has been written in terms of their numbers and how universities accommodate Chinese students is limited. It is imperative in servicing this population that universities first need to better understand the reasons then colleges and universities in the U.S. can build programs to cater to the long term facilitation of this segment market.

Future empirical studies may also focus the life style and living of these Chinese students in the U.S. or elsewhere, as many participate in this study, live together, and speak their own language, and it seems there is a battier between this market segment and the rest of local and international students. A further recommendation would be to look at any major differences between undergraduate and graduate Chinese students as well as differences between graduate Chinese who have completed bachelor degrees in the U.S. and those who haven't. 
The growing number of the Chinese students in the U.S. has raised some challenging questions for both educators and researchers. In the future, researchers will need to know more about: what are the expectations of these Chinese students when they land in the U.S.? Are their expectations met during their studies or after their studies? If their expectations are not met, what educators in the U.S. schools need to do? A demographic of this size cannot be ignored and needs to be better understood.

\section{REFERENCES}

[1] 2016 Top Markets Reports Education, US Department of Commerce, May $2016 . \quad$ Source: https://www.trade.gov/topmarkets/pdf/Education_Top_Markets_Report.pdf

[2] Albrecht, C, Malagueno, R., Holland, D., and Sanders, M. (2012). Cross cultural management: an international journal, 19(4), 433-454.

[3] Chao, C. \& Hegarty, N. (2014). Driving forces which enthuse the continuous growth of Chinese students in U.S. colleges: a preliminary study on Chinese students' motives, Journal of Academic Administration in Higher Education, fall, 10(2), 27-34.

[4] The Chinese-American Museum of Chicago (1880). Comparing Japanese and Chinese students at U.S. universities, retrieved from https://p.widencdn.net/ymtzur/Open-Doors-2017-Country-Sheets-China

[5] Conover, W. J. (1980). Practical nonparametric statistics (2nd ed.). New York: John Wiley \& Sons, (pp. 213-337, pp.344-384).

[6] Davis, D., \& R. M. Cosenza (1985). Business research for decision making, Boston, Kent Publishing Company.

[7] Hamburg, M. (1977). Statistical analysis for decision making (2nd ed.). Harcourt Brace Jovanovich, Inc., New York, (pp. 219 538).

[8] Henze, J., \& Zhu, J. (2012). Current research on Chinese students studying abroad, Research in Comparative and International Education, 7(1), 90-104.

[9] IIE DATA, (2017). Retrieved from https://www.iie.org/Research-and-Insights/Open-Doors/Data/InternationalStudents/Fields-of-Study; November 2017

[10] Joseph, F. (2012, October 19). Overseas colleges fight for Chinese students, CNTV.

[11] Meckler, L. \& Korn, M. (2018). Visas Issued to Foreign Students Fall, Partly Due to Trump Immigration Policy, the Wall Street Journal, March 11, 2018. Retrieved from https://www.wsj.com/articles/visas-issued-to-foreign-studentsfall-partly-due-to-trump-immigration-policy-1520766000? $\mathrm{mod}=$ searchresults $\&$ page $=1 \&$ pos $=6$

[12] NAFSA, Report (2016). Retrieved from https://istart.iu.edu/nafsa/reports/state.cfm?state=NY\&year=2016

[13] NAFSA, Report (2017). The economic benefit of international students, \$36.9 billion contributed and 450,311 U.S. jobs supported, NAFSA International Student Economic Value Tool. Retrieved from http://www.nafsa.org/Policy_and_Advocacy/Policy_Resources/Policy_Trends_and_Data/NAFSA_International_Stu dent_Economic_Value_Tool/

[14] Ortiz, A., Chang, L. \& Fang, Y. (2015). International student mobility trends 2015: an economic perspective, Social Science Research Network, February 2. Retrieved from http://wenr.wes.org/2015/02/international-student-mobilitytrends-2015-an-economic-perspective/

[15] Ozturgut, O. \& Murphy, C. (2009). Literature vs. practice: challenges for international students in the U.S., International Journal of Teaching and Learning in Higher Education, 22(3), 374-385.

[16]Report of Open Door, Institute of International Education (IIE) (2017). Retrieved from https://www.iie.org/Research-and-Insights/Open-Doors/Data/Economic-Impact-of-International-Students

[17] Ruiz, N. G. (2014, August 29). The Geography of Foreign Students in U.S. Higher Education: Origins and Destinations, Brookings. Retrieved from http://www.brookings.edu/research/interactives/2014/geography-offoreign-students\#/M10420

[18] Russell, J., Rosenthal, D. and Thomson, G. (2010). The international student experience: three styles of adaptation, Higher Education, 60(2), 235-249.

[19] Soria1, K. M. \& J. Troisi (2014, July 1). Internationalization at Home Alternatives to Study Abroad, Journal of Studies in International Education, 18: 261-280

[20] Taylor, A. (2012, October). Three Reasons China's Students are Desperate to Study in America, Business Insight.

[21]U.S. News and World Report, (2017). Retrieved from https://www.usnews.com/education/best-globaluniversities/rankings?page $=7$

[22] WES Report: International trend in higher education, an Oxford Report (2015). Retrieved from https://www.ox.ac.uk/sites/files/oxford/International\%20Trends\%20in\%20Higher\%20Education\%202015.pdf 
[23] Wu, Q. (2014, November). Reasons and decision-making processes of mainland Chinese students for undertaking master's programs abroad, Journal of Studies in International Education. 18(5). 426-444.

[24] Yan, A. (2015, March 25). Why Chinese parents are sending their children abroad to study at a younger age, South China Morning Post. Retrieved from http://www.scmp.com/news/china/article/1747075/why-mainland-parents-aresending-their-children-abroad-study-younger-age?page=all

[25]Zheng, X. (2010). Re-interpreting silence: Chinese international students' verbal participation in U.S. universities, The International Journal of Learning, 17(5), 451-464. 